\title{
Floristic Composition, Structure, and Species Associations of Dry Miombo Woodland in Tanzania
}

\author{
Ezekiel Edward Mwakalukwa, ${ }^{1,2}$ Henrik Meilby, ${ }^{1}$ and Thorsten Treue ${ }^{1}$ \\ ${ }^{1}$ Department of Food and Resource Economics, Faculty of Science, University of Copenhagen, Rolighedsvej 23, \\ 1958 Frederiksberg C, Denmark \\ ${ }^{2}$ Department of Forest Biology, Faculty of Forestry and Nature Conservation, Sokoine University of Agriculture, \\ P.O. Box 3010, Chuo Kikuu, Morogoro, Tanzania
}

Correspondence should be addressed to Ezekiel Edward Mwakalukwa; ezedwa@yahoo.com

Received 20 December 2013; Accepted 4 February 2014; Published 8 May 2014

Academic Editors: M. Drielsma, H. Ford, M. Tigabu, and A. Viña

Copyright (C) 2014 Ezekiel Edward Mwakalukwa et al. This is an open access article distributed under the Creative Commons Attribution License, which permits unrestricted use, distribution, and reproduction in any medium, provided the original work is properly cited.

\begin{abstract}
For the majority of forest reserves in Tanzania, biodiversity is poorly documented. This study was conducted to assess species richness (woody species), diversity, and forest structure and to examine relationships between species occurrence and topographic and edaphic factors in the Gangalamtumba Village Land Forest Reserve, a dry Miombo woodland area in Tanzania. A total of 35 nested circular plots with radii of 5, 15, and $20 \mathrm{~m}$ were used to collect data on woody species and soil samples across the 6,065 ha community-managed forest reserve. Stumps were measured $20 \mathrm{~cm}$ above ground. A total of 88 species belonging to 29 families were identified. Generally forest structure parameters and diversity indices indicated the forest to be in a good condition and have high species richness and diversity. Vegetation analysis revealed four communities of which two were dominated by the family Caesalpiniaceae, indicating large variation of site conditions and possible disturbances in the study area. The high level of diversity of woody species and the high basal area and volume indicate that the forest is in good condition, but the effect of anthropogenic activities is evident and stresses the need for proper management to maintain or enhance the present species diversity.
\end{abstract}

\section{Introduction}

Miombo woodland is the most widespread and dominant dry forest formation in Eastern, Central, and Southern Africa. It is characterized by an abundance of tree species in the legume subfamily Caesalpinoideae, including the three dominant genera of Brachystegia, Julbernardia, and Isoberlinia $[1,2]$. Covering an area of about 3.6 million $\mathrm{km}^{2}$, miombo woodland supports the livelihoods of more than 100 million rural and urban dwellers by providing a wide range of products such as firewood, charcoal, timber, and forage and services such as soil conservation and water catchment [3-5]. However, due to the rapid population growth and the high level of poverty across the Miombo region, the human pressure on its woodlands has steadily increased over the last decades, leading to increasing deforestation and forest degradation [6-8].

The effects of increasing rates of deforestation and forest degradation on biodiversity in developing countries have been thoroughly studied [9-12]. Habitat loss due to deforestation reduces not only the number of species in the ecosystem but also the number and extent of places where species coexist. Activities such as charcoal production, firewood collection for subsistence use and for tobacco curing, conversion of woodlands to farmland, and seasonal forest fires are among the major drivers of deforestation and forest degradation in the Miombo region [13-17]. It is estimated that 1.4 million ha of woodlands is lost annually in the countries where Miombo woodlands dominate, leading to a loss of carbon stocks, biodiversity, and, through soil degradation, loss of plant nutrients $[4,5]$. Syampungani et al. [5, p. 151] stated that "loss of biodiversity and extinction of most of the woodland resources are imminent if the current intensive exploitation of Miombo resources continues unchecked." More specifically, FAO (2000a, cited by Syampungani et al. [5]) reported that 191 tree species in the Miombo ecoregion are endangered due 


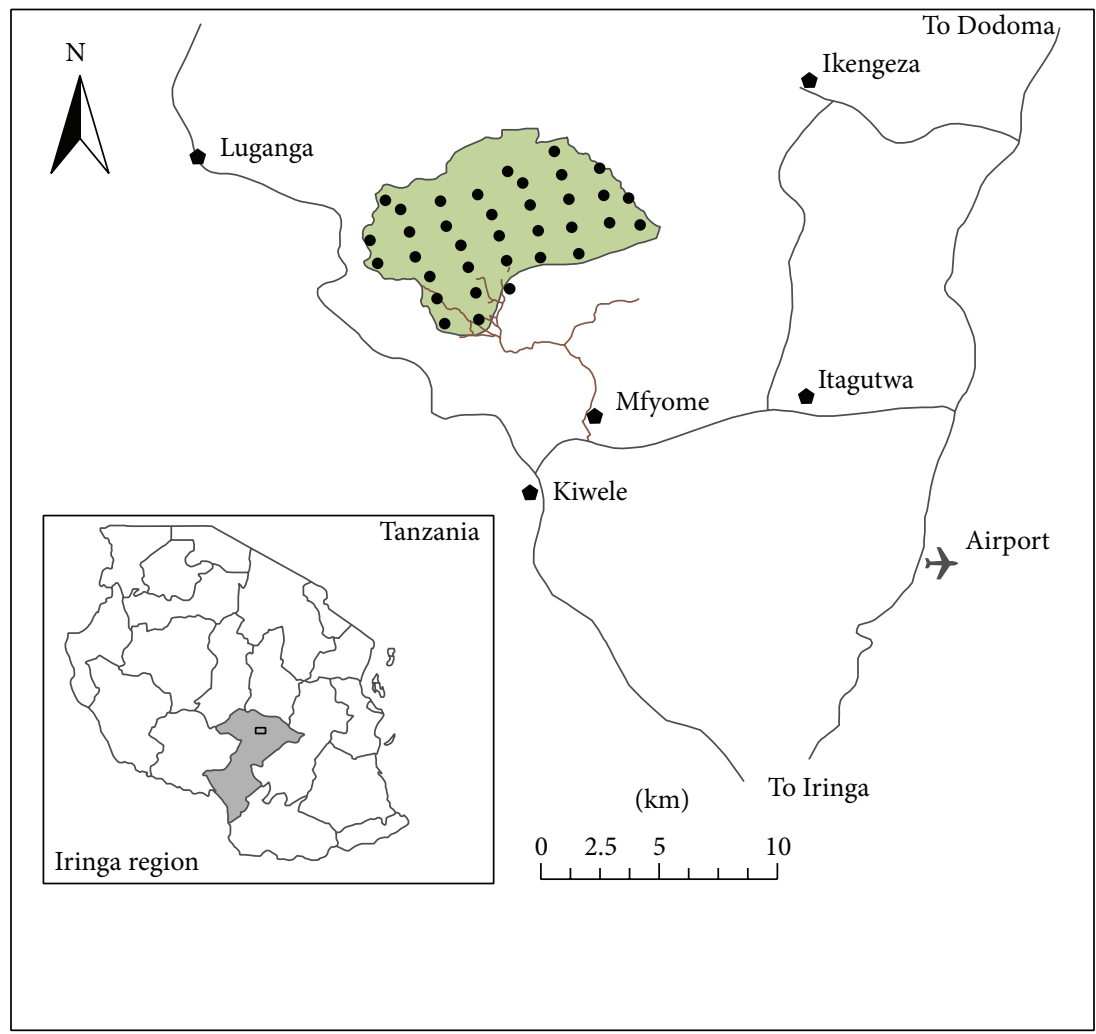
- Plots
- Villages
— Forest roads
Dirt roads
$\square$ Gangalamtumba forest reserve

Figure 1: Map showing the location of the study area. The inserted map of Tanzania shows the location of the Iringa region.

to conversion of forest areas into agricultural lands or through charcoal production.

Gangalamtumba Village Land Forest Reserve (GVLFR) in Iringa rural district, Tanzania, which is owned and managed by the village of Mfyome, was established in 2002 under Tanzania's national participatory forest management programme and thus represents one of approximately 1500 Village Land Forest Reserves (covering some 2.4 million ha), the progressive establishment of which is intended to promote conservation of approximately 16.5 million ha of hitherto unreserved forest on general and village land [18-21]. Villages' control over Village Land Forest Reserves is conditional on their conservation/protection of these forests and the executive management is performed by an environmental/forest management committee whose members are directly elected for five-year terms by all members of the village above the age of 18 [18]. As such GVLFR is a typical example of an area which, at least until 2002, might have experienced loss of biodiversity due to increasing human activity, including charcoal production and extraction of wood for tobacco curing, giving cause for concern with respect to the maintenance of forest biodiversity [15]. The extent to which the activities have led to loss of biodiversity and deterioration of the plant community structure is so far unknown, but for the development of sustainable woodland management strategies and for planning of future management and conservation, information on these issues is urgently needed.

Although many quantitative ecological studies have been undertaken in places where Miombo dominates, its extensiveness and the large between-site variation, which is caused by climatic and edaphic factors and anthropogenic activities, appear to warrant further case studies [20, 22-29]. Ecological case studies are particularly relevant when the information generated is required for sound decision making about forest management, conservation strategies, and determination of sustainable harvesting levels. Hence, the objectives of this study were (1) to provide a detailed assessment of the current standing stock, species diversity, richness, and structure and (2) to understand the relationship between species abundance and a range of environmental and topographic factors that shape plant communities and species associations in the GVLFR.

\section{Materials and Methods}

2.1. Study Site. Gangalamtumba Village Land Forest Reserve is located in central-southern Tanzania $\left(7^{\circ} 35^{\prime} \mathrm{S} ; 35^{\circ} 35^{\prime} \mathrm{E}\right)$, about $30 \mathrm{~km}$ north of Iringa town, the administrative capital of the Iringa region (Figure 1). The forest covers 6,065 hectares and is part of the Mfyome village area, which is located in 
the ward of Kiwele. The forest vegetation has been described as dry Miombo woodland, similar to the dry woodland type described from other countries such as Zimbabwe and Mozambique [1]. The forest is located in a relatively flat area at an elevation of $850-1,300$ metres above sea level. The region is characterised by distinct wet and dry seasons with almost no rain in the four months of June-September and about $80 \%$ of the annual precipitation falling in DecemberMarch. Average rainfall data covering the last 50 years (19602010) were obtained from the meteorological station at Nduli airport, which is located about $30 \mathrm{~km}$ from the forest, and indicate that the area receives an average annual precipitation (mean \pm standard error) of $617 \pm 17 \mathrm{~mm}$ (448-1085 mm). The mean annual temperature is $19.8^{\circ} \mathrm{C}$ and the average relative humidities at 06.00 and 12.00 GMT are $53.9 \%$ and $51.4 \%$, respectively.

The GVLFR is a production forest which is managed by the Mfyome village under a community-based forest management (CBFM) arrangement established in 2002; compare above. The primary economic activity in Mfyome is smallholder agriculture, and the main economic uses of the forest are production of timber, charcoal, and firewood [20]. The woodland is also used for grazing and is an important source of subsistence products such as firewood, construction materials, fruit, mushrooms, wild vegetables, and medicinal plants [18].

2.2. Vegetation Survey. The field survey was conducted in July and August 2009 and involved establishment of a total of 35 permanent, nested circular sample plots distributed across the entire forest. Plots were established along transect lines and the distance between plots was approximately $2 \mathrm{~km}$ (Figure 1). The radii of the nested circular plots were $5 \mathrm{~m}$ (0.0079 ha), $15 \mathrm{~m}$ (0.0707 ha), and $20 \mathrm{~m}$ (0.1257 ha). The following parameters were recorded within each of the 35 plots: within the $5 \mathrm{~m}$ radius all small trees and shrubs $(<150 \mathrm{~cm}$ tall or $\geq 150 \mathrm{~cm}$ but $<1 \mathrm{~cm} \mathrm{Dbh})$ were counted and their species were identified, and medium-size trees and shrubs ( $\geq 1 \mathrm{~cm}$ Dbh but $<5 \mathrm{~cm}$ Dbh) were identified and measured with respect to diameter. Within $15 \mathrm{~m}$ radius, the species were identified and the diameter was measured for all large trees and shrubs with $\mathrm{Dbh} \geq 5 \mathrm{~cm}$. Within $20 \mathrm{~m}$ radius, all stumps of trees and shrubs were identified to species level and measured for diameter $20 \mathrm{~cm}$ above ground. Initial identification of species for both standing trees/shrubs and stumps relied on the knowledge of local botanists (using local vernacular species names and features such as color of the bark, smell, and leaves) and was later confirmed by botanists from Tanzania Forest Research Institute (TAFORI) based at Lushoto Silviculture Research Station. For species that were difficult to identify in the field, samples were taken to the herbarium at Lushoto for reidentification. Other measurements taken within the plots were geographical location (UTM coordinates) and elevation (m) using GPS and slope (\%) using a Suunto clinometer.

2.3. Soil Sampling. Soil samples were collected from five points, which were located at the centre of the plot and $10 \mathrm{~m}$ from the centre in the four cardinal directions (North, East,
South, and West). At each point two samples were taken, 0$15 \mathrm{~cm}$ and $15-30 \mathrm{~cm}$ below the surface. The five samples taken from each depth range were mixed in the field to obtain one composite sample per depth range and plot. Thus, 70 soil samples (35 from each depth range) were collected from the 35 plots. In addition, a soil core device with an inner diameter of $5 \mathrm{~cm}$ and a length of $5 \mathrm{~cm}$ was used for extracting soil bulk density samples from the centre of each plot and at each depth. Hence, a total of 70 samples were collected for bulk density determination.

2.4. Laboratory Analyses. In the laboratory all soil samples were ground and passed through a $2 \mathrm{~mm}$ sieve to remove stones and gravel. Fine and coarse roots were also removed. Subsequently, soil samples collected at $0-15 \mathrm{~cm}$ depth were analysed for soil $\mathrm{pH}$, soil texture, cation-exchange capacity (CEC, cmol $(+) / \mathrm{kg})$, available phosphorus (ppm), and exchangeable bases $\left(\mathrm{Ca}^{2+}, \mathrm{Mg}^{2+}\right.$, and $\left.\mathrm{K}^{+}, \mathrm{cmol}(+) / \mathrm{kg}\right)$. Samples from both depth ranges $(0-15$ and $15-30 \mathrm{~cm})$ were analysed for percentages of organic carbon and total nitrogen. Standard methods for soil analysis were used in order to obtain estimates for each of the mentioned variables that can be compared with results reported in the literature [30-34]. Soil $\mathrm{pH}$ was determined electrometrically using $10 \mathrm{~g}$ of soil sample diluted in $25 \mathrm{~mL}$ distilled water, that is, using a $1: 2.5$ ratio of soil to water. Soil texture was determined by the hydrometer method and the textural classification was done by the use of the soil texture triangle [35].

The Bray 1 method was used for the determination of extractable $\mathrm{P}$ for acidic soils with $\mathrm{pH}$ less than 7 while the Olsen method was used for soils with $\mathrm{pH}$ above 7 (alkaline soils). The ammonium acetate method at $\mathrm{pH} 7$ was used in determination of CEC, and by the use of an atomic absorption spectrophotometer in a UNICAM 919 AA Spectrometer, all exchangeable cations $\left(\mathrm{Ca}^{2+}, \mathrm{Mg}^{2+}\right.$, and $\left.\mathrm{K}^{+}\right)$were determined. Subsamples were finely ground into powder form $(<1 \mathrm{~mm})$ in an agate mortar and analyzed for total percentages of organic $\mathrm{C}$ and $\mathrm{N}$ by dry combustion (Dumas method) in a Leco CNS 2000 analyzer [33]. Samples for bulk density estimation were oven-dried at $105^{\circ} \mathrm{C}$ to constant weight and the weight was recorded (accuracy $0.01 \mathrm{~g}$ ). The volume was calculated from length and cross-sectional area of the soil core, and bulk density was determined as dry weight $(\mathrm{g})$ per unit volume $\left(\mathrm{cm}^{3}\right)$. Most analyses were conducted at the Laboratory of Forest Biology, Sokoine University of Agriculture (SUA), but C and $\mathrm{N}$ analyses were conducted at the Soil Science Laboratory at the Department of Forest and Landscape (now Department of Geosciences and Natural Resource Management), University of Copenhagen, Denmark.

2.5. Data Analysis. Based on the data collected the following measures were analysed: species composition was expressed through species richness and diversity measures; forest structure was expressed through stem density, basal area and volume for plant communities, species groups, and diameter classes. Total species richness was computed as the total number of species across all 35 plots. Species diversity was computed using Shannon's and Simpson's Diversity Indices 
[36]. The volume of stumps was calculated as cylinder volume while total volume for standing trees was calculated using a regression equation developed for GVLFR by the authors $[37,38]: \ln (V)=-8.4554+2.3236 \times \ln (\mathrm{Dbh})\left(R^{2}=0.983\right.$, RMSE $=0.248$, Dbh range: $1.4-62 \mathrm{~cm}, n=104)$, where $V$ is volume $\left(\mathrm{m}^{3} /\right.$ tree); Dbh is diameter at breast height $(\geq 1 \mathrm{~cm})$, RMSE is the residual standard error, $R^{2}$ is the coefficient of determination, $n$ is the total sample size, and $\ln$ is the natural logarithm. The Importance Value Index (IVI) for each species in each plot was calculated as the sum of relative density and dominance (basal area) and expressed in percent [39]. Percentage base saturation (\%BS) was determined as the ratio of total base cation concentration to CEC, while the $\mathrm{C}: \mathrm{N}$ ratio was determined using the estimated elemental percentages of carbon and nitrogen [35].

Using IVI for each species, plots were classified by agglomerative hierarchical cluster analysis using Sørensen's distance measure and a group linkage method with flexible $\beta$ of -0.50 . The 35 plots were ordinated by nonmetric multidimensional scaling (NMS) using the PC_ORD software version 6.0 [40]. Topographic variables (elevation and slope) and edaphic variables $(\mathrm{pH}$, bulk density, texture, extractable $\mathrm{P}, \mathrm{CEC}$, exchangeable base cations, \%BS, $\mathrm{C}: \mathrm{N}$ ratio, \%C, and $\% \mathrm{~N})$ were correlated with the NMS ordination axes. Indicator/dominant species in each cluster were determined using percentage indicator values (\%IV) where values of 0 correspond to no indication and 100 is perfect indication [41, 42]. The first three to five names of these Indicator/dominant species with the highest percentage indicator values (\%IV), constancy, and significant indicator values $(P<0.05)$ were used to assign names to the clusters/plant community types $[29,41,42]$. The Steinhaus (Sørensen/Czekanowski) coefficient was used to assess the similarity/dissimilarity of the species compositions of the plant communities [39].

\section{Results}

3.1. Species Richness. Including all size categories a total of 88 species (29 plant families) of standing trees and shrubs/small trees were identified in the GVLFR (Table 1). Trees contributed 60\% (21 plant families) and shrubs $40 \%$ (15 plant families) of the species. For stumps, a total of 42 species (20 plant families) of trees and shrubs/small trees, with basal diameter ranging from 2 to $50 \mathrm{~cm}$, were identified. For stumps, trees contributed $76 \%$ (13 plant families) of the species while shrubs contributed $24 \%$ (10 plant families). All species represented by stumps were also represented by standing trees/shrubs. In general, tree and shrub species from the family Caesalpiniaceae contributed most (13\%) to the total number of species (standing individuals), followed by those from the families Mimosaceae (10\%), Rubiaceae (10\%), Fabaceae (9\%), and Euphorbiaceae (9\%) (Table 1). Among standing trees, the greatest number of species was found in the four plant families: Caesalpiniaceae (17\%), Mimosaceae (15\%), Fabaceae (13\%), and Combretaceae (9\%), while shrubs/small trees included most species from the families Rubiaceae (26\%), Euphorbiaceae (17\%), and Capparaceae $(9 \%)$. For stumps, tree and shrub species from

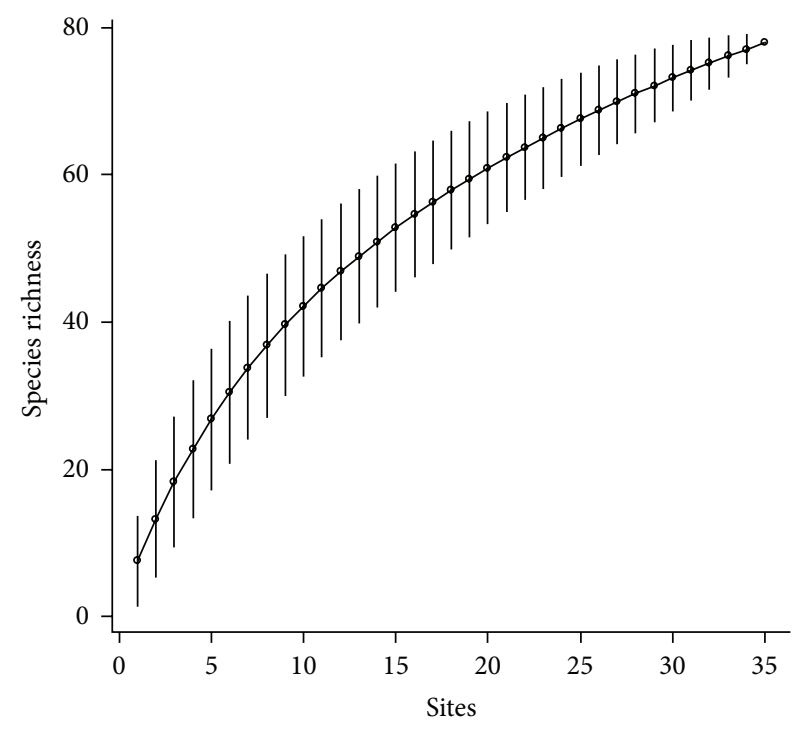

FIGURE 2: Species accumulation curve for large individuals (Dbh $\geq 5 \mathrm{~cm}$ ) measured within circular plots with a radius of $15 \mathrm{~m}$ in the Gangalamtumba VLFR. Vertical lines indicate standard deviations (range 0-4.9).

the family Mimosaceae contributed most (17\%) to the total number of species, followed by species from the families Caesalpiniaceae (14\%), Combretaceae (10\%), and Fabaceae (7\%). Among species categorised as trees, the families Caesalpiniaceae (19\%) and Mimosaceae (19\%) contributed equal numbers of species, followed by Combretaceae (13\%) and Fabaceae (9\%). With respect to shrubs each of the families was represented by a single species $(10 \%$; see Table 1$)$.

When considering different size categories and including both trees and shrubs (small sizes, Dbh $<5 \mathrm{~cm}$ and large sizes, Dbh $\geq 5 \mathrm{~cm}$ ), a total of 78 species (28 families) were found among large sizes, with Caesalpiniaceae (13\%), Mimosaceae (12\%), and Fabaceae (10\%) being the most species-rich plant families, while among small sizes, a total of 69 species (27 families) were observed, with Rubiaceae (13\%), Caesalpiniaceae (12\%), and Mimosaceae (10\%) contributing the greatest number of species (Table 1). In general the average number of species per plot was found to be 14 species (range 5-24 species per plot).

The species accumulation curve (Figure 2) shows that the 35 sites/plots used in this study were sufficient to cover much (but not all) of the variation and species diversity of the study area. At 35 plots the graph has not yet reached its asymptotic level but is starting to converge, implying that any further increase of sample size would be expected to lead to inclusion of additional rare species. However, although the sample size was small (35 plots) and does not quite capture the full woody plant biodiversity of the reserve, the results are still useful for characterizing the tree/shrub species diversity and relationships between species and site.

3.2. Species Diversity. Shannon-Wiener diversity indices for large and small individuals were found to be 3.44 and 3.26, respectively, and the Simpson index for large individuals was 


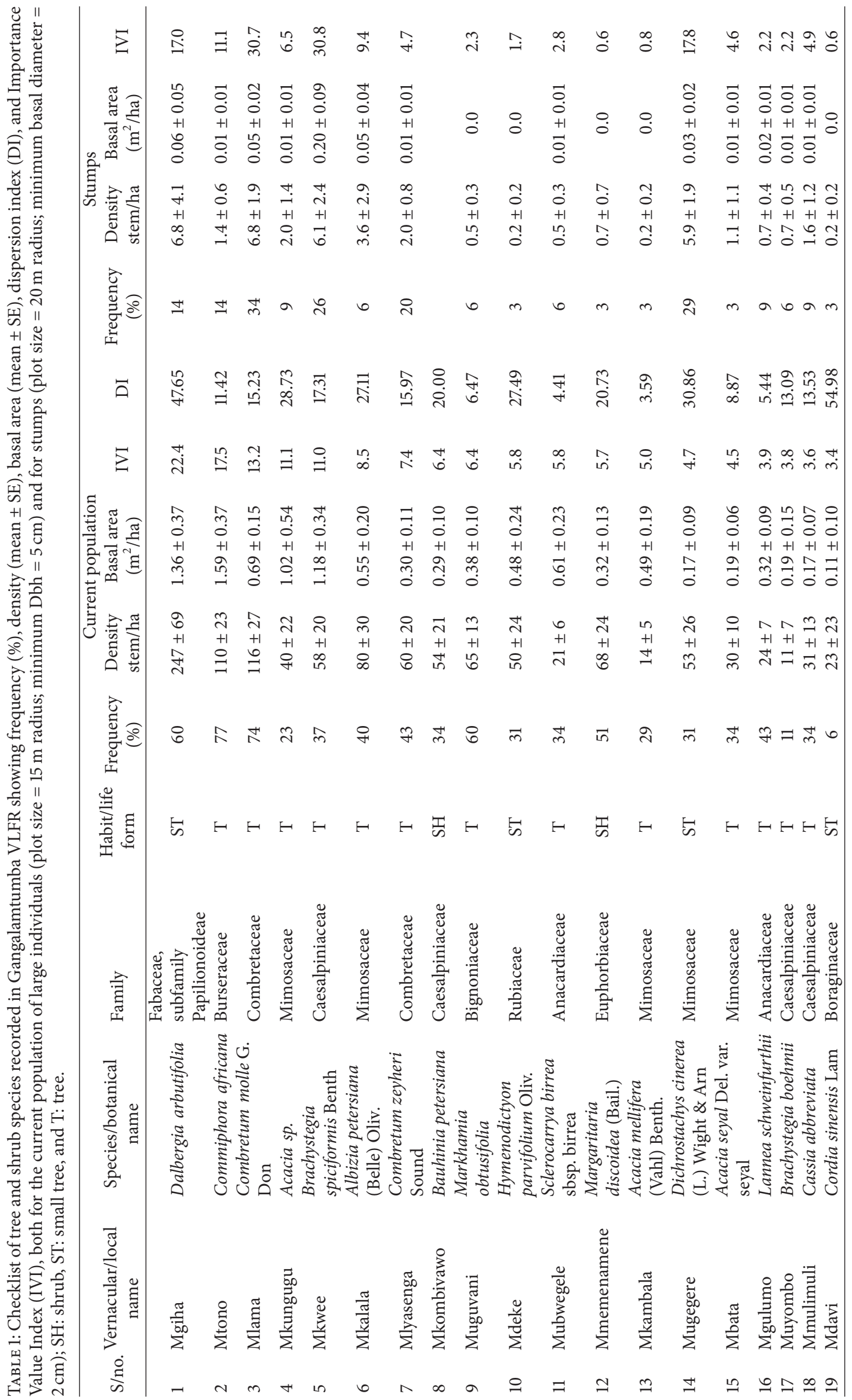




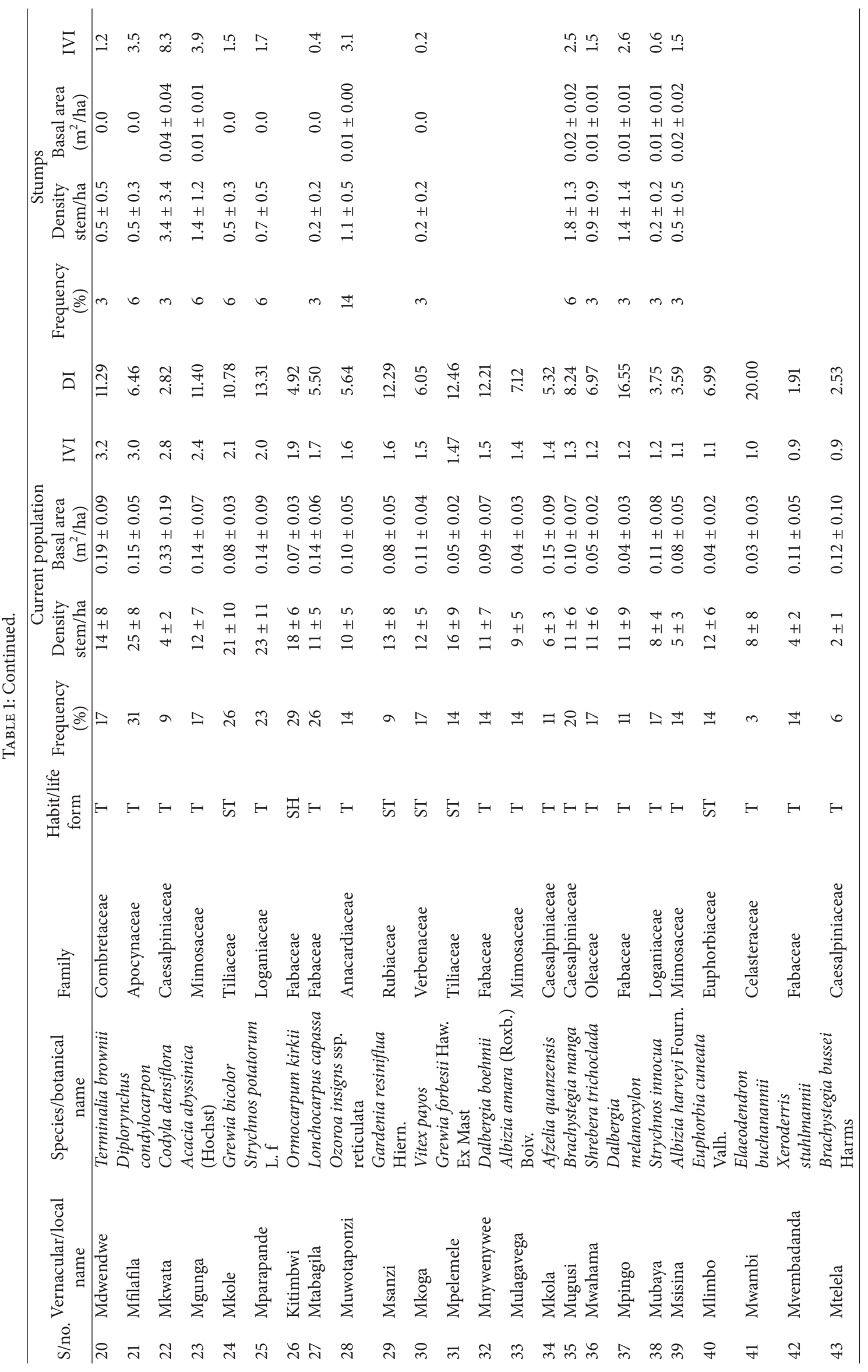




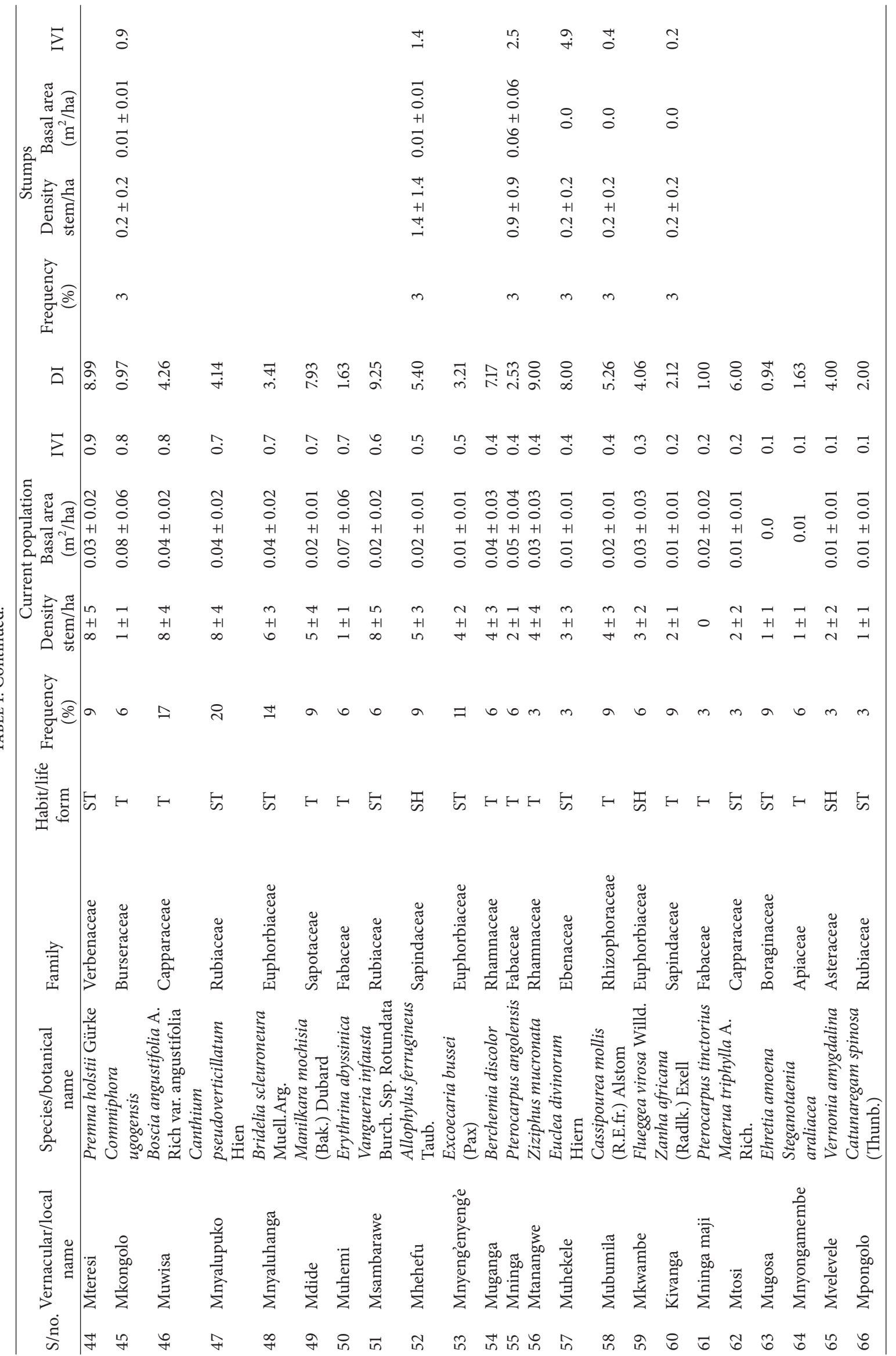




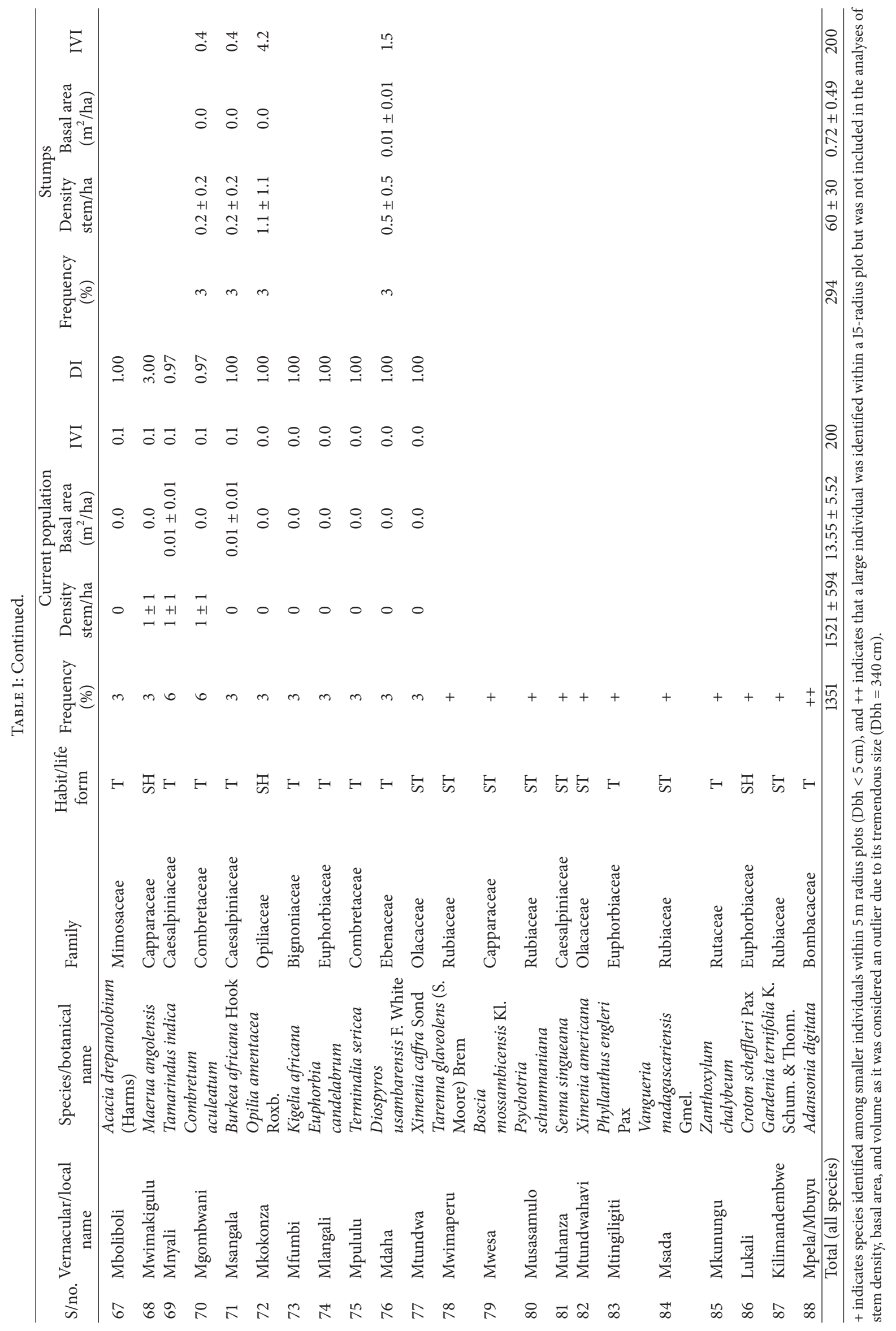


0.05 and that of small individuals was 0.06 . The following species were observed to have the greatest contributions to the Shannon-Wiener diversity index of large individuals: Dalbergia arbutifolia (contributing 0.30), Combretum molle (0.20), Commiphora africana (0.19), Albizia petersiana (0.16), and Margaritaria discoidea (0.14), while for smaller ones the greatest contributions were found for Brachystegia spiciformis (0.26), Dalbergia arbutifolia (0.24), Grewia forbesii (0.23), Margaritaria discoidea (0.20), and Dichrostachys cinerea (0.16). In terms of frequency of occurrence for standing individuals (large sizes) Commiphora africana was the most frequent species (77\% of plots), followed by Combretum molle (74\%) and Dalbergia arbutifolia (60\%), while for small sizes Margaritaria discoidea (66\%), Markhamia obtusifolia (63\%), and Dalbergia arbutifolia (57\%) were the most frequent species. The Importance Value Index (IVI) for large individuals (Dbh $\geq 5 \mathrm{~cm}$ ) shows that Dalbergia arbutifolia (22.4), Commiphora africana (17.5), and Combretum molle (13.2) were the most important species among standing individuals, while Brachystegia spiciformis (30.8), Combretum molle (30.7), and Dichrostachys cinerea (17.8) appeared to be the most important among harvested individuals (stumps). These species were also found to have higher frequencies than any other harvested species observed in the GVLFR (Table 1).

3.3. Stem Density. The total mean stem density for large individuals with $\mathrm{Dbh} \geq 5 \mathrm{~cm}$ was $1521 \pm 594$ stems/ha (Table 1) and that of small individuals with $\mathrm{Dbh}<5 \mathrm{~cm}$ (including individuals with $\mathrm{Dbh}<1 \mathrm{~cm}$ ) was $14318 \pm 6956$ stems/ha. Among large individuals the most abundant species were Dalbergia arbutifolia (16.2\% of 1521 stems/ha), Combretum molle (8\%), Commiphora africana (7.2\%), and Albizia petersiana (5.3\%). Among small individuals, the most abundant species were Brachystegia spiciformis (13\% of 14318 stems/ha) followed by Dalbergia arbutifolia (11\%) and Grewia forbesii (10\%). For stumps, the overall mean density was $60 \pm$ 38 stems/ha, with Combretum molle (12\%), Dalbergia arbutifolia (12\%), Brachystegia spiciformis (10\%), and Dichrostachys cinerea (10\%) contributing the most (Table 1). Generally, the distribution of standing trees to size classes showed the usual reverse J shape, which was also approximately observed for stumps (Figure 3). However, for stumps the density of stems in the $1-10 \mathrm{~cm}$ diameter class was slightly lower than what would be expected if tree felling had been a random event.

3.4. Basal Area. For the GVLFR as a whole the mean basal areas for large $(\geq 5 \mathrm{~cm}$ Dbh) and small individuals $(<5 \mathrm{~cm} \mathrm{Dbh})$ were $13.55 \pm 5.52 \mathrm{~m}^{2} /$ ha (Table 1 , Figure 4$)$ and $3.05 \pm 0.02 \mathrm{~m}^{2} / \mathrm{ha}$, respectively. The species contributing most to the basal area of large individuals were Commiphora africana (12\%), Dalbergia arbutifolia (10\%), and Brachystegia spiciformis (9\%), while those contributing most to the basal area of smaller individuals were Dalbergia arbutifolia (16\%), Grewia forbesii (15\%), and Dichrostachys cinerea (13\%). The mean basal area for stumps was $0.72 \mathrm{~m}^{2} /$ ha with Brachystegia spiciformis contributing the greatest individual proportion (28\%); 41 species made up the rest (Figure 4).

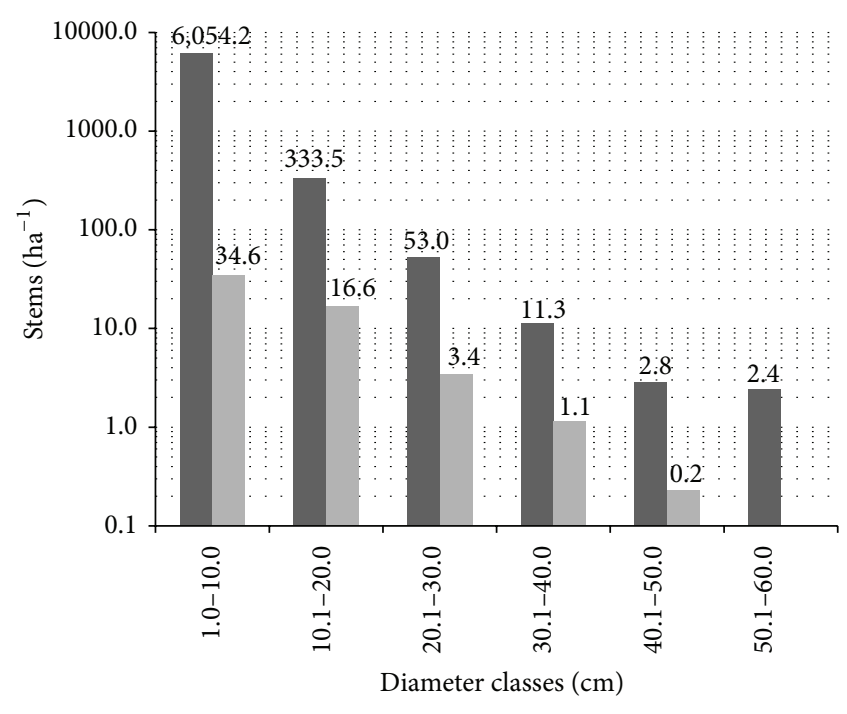

- Standing trees

- Stumps

FIGURE 3: Density of standing trees $\geq 1 \mathrm{~cm}$ Dbh and stumps $\geq 1 \mathrm{~cm}$ by diameter class in Gangalamtumba VLFR $(n=35)$. NB: logarithmic scale on vertical axis.

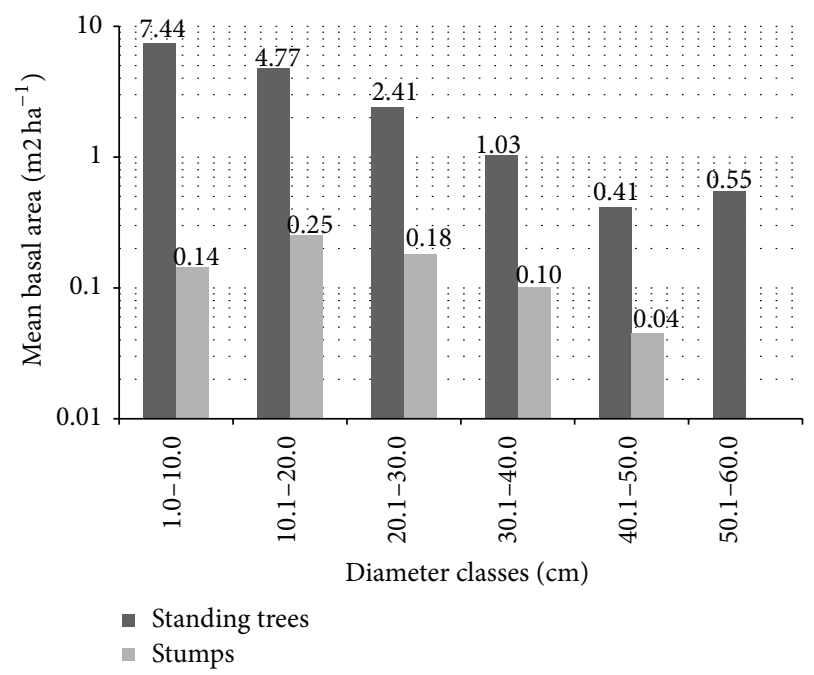

FIgURE 4: Distribution of basal area per hectare for standing trees $\geq 1 \mathrm{~cm}$ Dbh and stumps $\geq 1 \mathrm{~cm}$ by diameter classes in the Gangalamtumba VLFR $(n=35)$. NB: logarithmic scale on vertical axis.

3.5. Volume. The mean volumes for large ( $\geq 5 \mathrm{~cm} \mathrm{Dbh})$ and small individuals $(<5 \mathrm{~cm} \mathrm{Dbh})$ were $92.17 \pm 39.0 \mathrm{~m}^{3} /$ ha and $12.57 \pm 6.35 \mathrm{~m}^{3} / \mathrm{ha}$, respectively (not shown in tables). The species contributing most to the volume of large individuals were Commiphora africana (12\%), Brachystegia spiciformis (10\%), Acacia sp. (9\%), and Dalbergia arbutifolia (9\%). For smaller individuals, the species that contributed most to volume were Dalbergia arbutifolia (16\%), Grewia forbesii (14\%), and Dichrostachys cinerea (13\%). The mean remaining volume of stumps was found to be $0.15 \pm 0.1 \mathrm{~m}^{3} /$ ha with Brachystegia spiciformis contributing the greatest individual percentage (28\%); 41 species made up the rest. 
3.6. Spatial Distribution. Dispersion indices (DI) are presented for individual species in Table 1 . The dispersion index values range from 0.94 , indicating almost complete spatial randomness or slight underdispersion, to 54.98, indicating considerable overdispersion, that is, a patchy or clustered distribution. Out of 77 species, excluding the single, very large Adansonia digitata that was considered an outlier, 64 species (83\%), 9 species (12\%), and 4 species (5\%) were found to have DI $>1, \mathrm{DI}=1$, and DI $<1$, respectively, so the majority of species are characterised by a patchy distribution across the forest. The species with the lowest estimated DI was Ehretia amoena (0.94) while the highest DI was estimated for Cordia sinensis (54.98). The most abundant species, including Dalbergia arbutifolia $(\mathrm{DI}=47.65)$, Combretum molle (DI = $15.23)$, and Commiphora africana (DI $=11.42$ ), are strongly overdispersed.

3.7. Plant Communities and Species Association. Four plant communities were identified through cluster analysis based on the statistical significance (5\%) of the observed maximum indicator values (Table 2). Only two of these plant communities were dominated by species from the family Caesalpiniaceae (Communities 1 and 24). The other two showed great variation/overlap between species of different plant families (Communities 3 and 5). The estimated Steinhaus similarity indices between pairs of plant communities varied from $32 \%$ for Communities 1 and 3 and Communities 5 and 24, to 37\% for Communities 3 and 5 (not shown in tables).

The ordination diagram (Figure 5) shows that one topographic and six edaphic variables appear to be associated with the four plant communities and the species distribution in the study area. The strongest correlation with community composition was observed for elevation, followed by soil $\mathrm{pH}$ at $0-15 \mathrm{~cm}$ depth, base cation $\mathrm{Ca}^{2+}$ at $0-15 \mathrm{~cm}$ depth, percent base saturation (\%BS) at $0-15 \mathrm{~cm}$ depth, percent clay at $0-15 \mathrm{~cm}$ depth, $\mathrm{C}: \mathrm{N}$ ratio at $15-30 \mathrm{~cm}$ depth, and percent sand at $0-15 \mathrm{~cm}$ depth. The base cations magnesium $\left(\mathrm{Mg}^{2+}\right)$ and potassium $\left(\mathrm{K}^{+}\right)$were not directly correlated with the community composition, but since they are included in the base saturation percentage they are indirectly related. Plant communities were ordered along the second ordination axis, which was positively correlated with $\mathrm{pH} 15(r=0.71)$, Ca15 $(r=0.69)$, BS $(r=0.65)$, and Clay15 $(r=0.52)$ and negatively correlated with Sand15 $(r=-0.46)$. Axis 1 of the ordination was positively correlated with Elev $(r=0.85)$ and CNrat30 $(r=0.51)$. As shown in Table 3 and indicated graphically in Figure 5 correlations between many of the edaphic variables are strong, particularly between pH15, Sand15, Clay15, Ca15, and BS, whereas correlation between topographic and most edaphic variables is small and nonsignificant. However, there is a significant negative correlation $(r=-0.42)$ between Elev and Sand15, indicating that sandy soils are mostly found at lower elevations.

\section{Discussion}

4.1. Species Composition. The results reported in this study show that the composition of the vegetation types found in

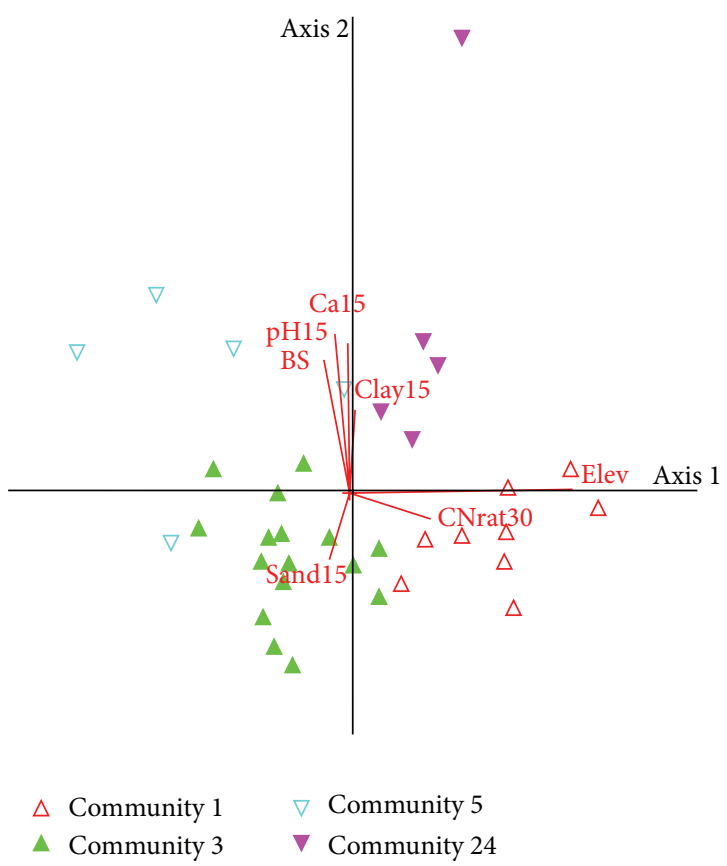

FIGURE 5: Compositional gradients and plant communities in NMS ordination of 35 vegetation plots for trees $\geq 5 \mathrm{~cm}$ in Gangalamtumba VLFR. Four plant communities are recognized (cf. Table 2). Community 1 = Brachystegia spiciformis, Diplorynchus condylocarpon, and Lannea schweinfurthii woodland; Community $3=$ Dalbergia arbutifolia, Commiphora africana, and Albizia petersiana woodland; Community 5 = Acacia sp., Acacia abyssinica, and Albizia amara woodland; and Community $24=$ Bauhinia petersiana and Shrebera trichoclada woodland. Elev: elevation $(\mathrm{m}) ; \mathrm{CNrat} 30: \mathrm{C}: \mathrm{N}$ ratio at 15-30 cm depth; Sand15: sand (\%) at 0-15 cm; Clay15: clay (\%) at 0$15 \mathrm{~cm}$; $\mathrm{Cal} 5=\mathrm{Ca}^{2+}(\mathrm{cmol}(+) / \mathrm{kg})$ at $0-15 \mathrm{~cm} ; \mathrm{pH} 15=$ soil $\mathrm{pH}$ at $0-$ $15 \mathrm{~cm}$; BS: \% base saturation at $0-15 \mathrm{~cm}$.

the GVLFR, especially the dominance of species from the family Caesalpiniaceae, agreed well with previous descriptions and classifications of plant communities commonly found in miombo woodlands [1]. However, the observed dominance based on IVI of the genera Dalbergia, Commiphora, and Combretum contrasts with patterns usually considered common for miombo woodlands. The frequency of species in these genera was also high compared to other species observed in the GVLFR (Table 1). Similar deviations exist between the results obtained by Banda et al. [26], in the Katavi-Rukwa ecosystem, where they observed that Terminalia and Combretum were the dominant genera, and the findings of Giliba et al. [27] and Njana [43], who both noted the dominance of the two common miombo genera Brachystegia and Julbernardia. However, Combretum also occurred in their study areas. The results suggest that on a larger spatial scale the species diversity of miombo woodlands is very high and that the three common genera Brachystegia, Julbernadia, and Isoberlinia are not always dominant at the local scale.

The species richness observed in the GVLFR compares well with miombo community studies in other areas of dry miombo in Tanzania and elsewhere, which receive an average 


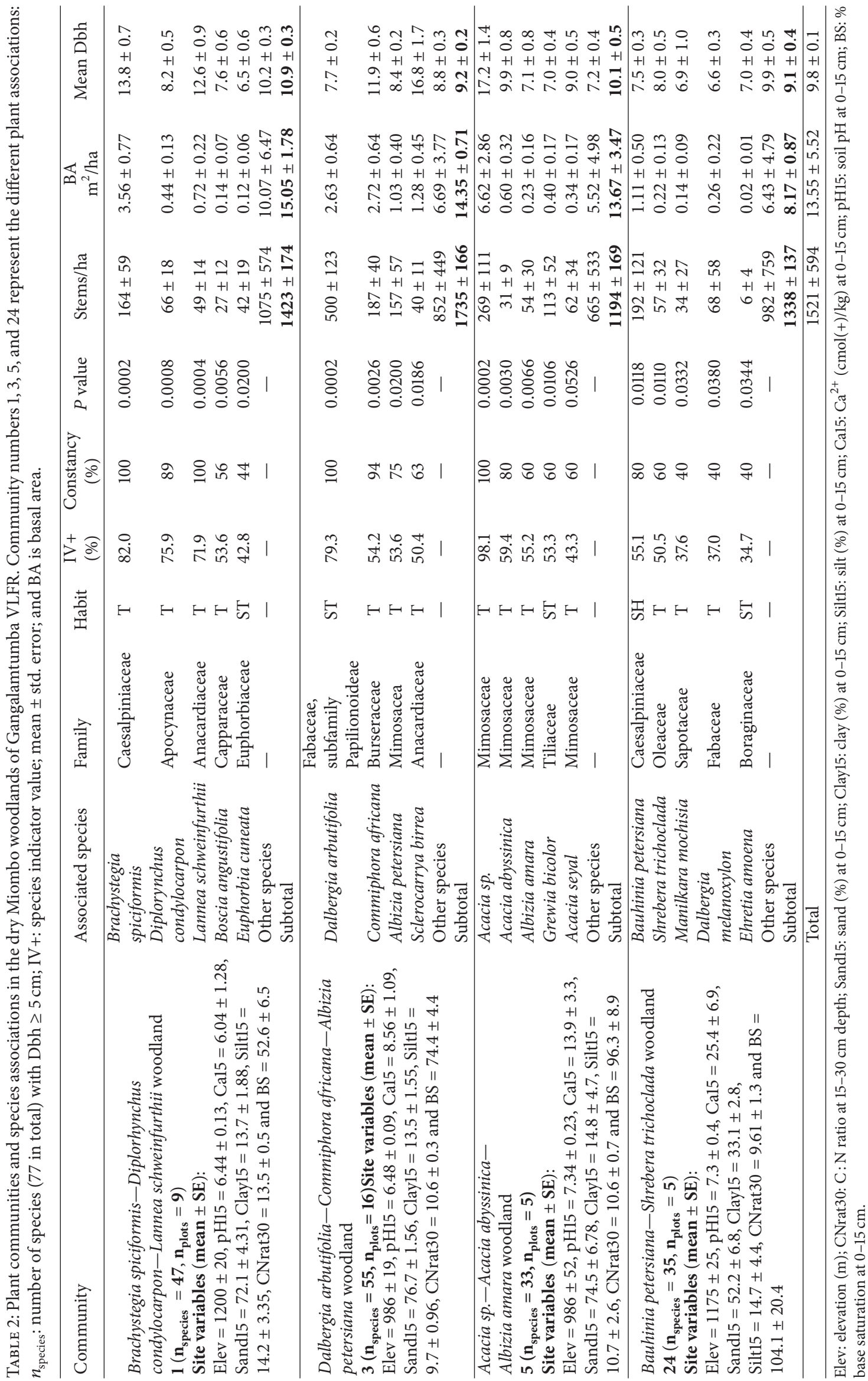


TABLE 3: Pearson-correlation matrix for two topographic and eight edaphic variables ${ }^{\dagger}$ associated with the classified plant communities in the Gangalamtumba VLFR $(n=35)$. Applied significance levels: ${ }^{*} 5 \%,{ }^{* *} 1 \%$, and ${ }^{* * *} 0.1 \%,{ }^{+}$not significant.

\begin{tabular}{|c|c|c|c|c|c|c|c|c|c|}
\hline & Elev & Slope \% & pH15 & Cal5 & K15 & N15 & Sand15 & Clay15 & CNrat30 \\
\hline Slope \% & $0.19^{+}$ & & & & & & & & \\
\hline pH15 & $-0.13^{+}$ & $-0.33^{*}$ & & & & & & & \\
\hline Ca15 & $0.02^{+}$ & $-0.20^{+}$ & $0.83^{* * *}$ & & & & & & \\
\hline K15 & $-0.29^{+}$ & $0.00^{+}$ & $0.10^{+}$ & $0.12^{+}$ & & & & & \\
\hline N15 & $0.06^{+}$ & $0.36^{*}$ & $0.10^{+}$ & $0.41^{* *}$ & $0.33^{*}$ & & & & \\
\hline Sand15 & $-0.42^{* *}$ & $0.03^{+}$ & $-0.53^{* * *}$ & $-0.74^{* * *}$ & $0.06^{+}$ & $-0.46^{* *}$ & & & \\
\hline Clay15 & $0.31^{+}$ & $-0.12^{+}$ & $0.51^{* *}$ & $0.76^{* * *}$ & $-0.01^{+}$ & $0.47^{* *}$ & $-0.86^{* * *}$ & & \\
\hline CNrat30 & $0.36^{*}$ & $0.10^{+}$ & $-0.39^{*}$ & $-0.51^{* *}$ & $-0.15^{+}$ & $-0.19^{+}$ & $0.40^{*}$ & $-0.48^{* *}$ & \\
\hline BS & $-0.24^{+}$ & $-0.17^{+}$ & $0.84^{* * *}$ & $0.91^{* * *}$ & $0.15^{+}$ & $0.37^{*}$ & $-0.58^{* * *}$ & $0.60^{* * *}$ & $-0.51^{* *}$ \\
\hline
\end{tabular}

${ }^{\dagger}$ Elev: elevation (m); pH15: soil pH at 0-15 cm; Ca15: $\mathrm{Ca}^{2+}(\mathrm{cmol}(+) / \mathrm{kg})$ at $0-15 \mathrm{~cm} ; \mathrm{K} 15: \mathrm{K}^{+}(\mathrm{cmol}(+) / \mathrm{kg})$ at $0-15 \mathrm{~cm}$; $\mathrm{N} 15: \% \mathrm{~N}$ concentration at $0-15 \mathrm{~cm}$; Sand15: sand (\%) at $0-15 \mathrm{~cm}$; Clay15: clay (\%) at $0-15 \mathrm{~cm}$; CNrat30: C: $\mathrm{N}$ ratio at $15-30 \mathrm{~cm}$ depth; BS: \% base saturation at $0-15 \mathrm{~cm}$. $t$-value was calculated as $t=r \sqrt{(n-2) /\left(1-r^{2}\right)}$, where $r$ is the Pearson-correlation coefficient and $n$ is the total sample size.

TABle 4: Species richness observed in other studies from dry miombo woodlands.

\begin{tabular}{lcccc}
\hline $\begin{array}{l}\text { Plot size } \\
\text { (ha) }\end{array}$ & $\begin{array}{c}\text { Total } \\
\text { number } \\
\text { of plots }\end{array}$ & $\begin{array}{c}\text { Total sample } \\
\text { area } \\
\text { (ha) }\end{array}$ & $\begin{array}{c}\text { Total number } \\
\text { of species }\end{array}$ & References \\
\hline 0.071 & 70 & 4.95 & 82 & {$[43]$} \\
0.071 & 80 & 5.65 & 110 & {$[27]$} \\
0.071 & 133 & 9.40 & 229 & {$[26]$} \\
0.071 & 247 & 17.46 & 102 & {$[44]$} \\
0.04 & 40 & 1.60 & 81 & {$[45]$} \\
0.25 & 14 & 3.50 & 69 & {$[25]$} \\
0.1 & 2 & 0.20 & 40 & {$[28]$} \\
0.1 & 152 & 15.20 & 92 genera & {$[22]$} \\
0.071 & 35 & 2.47 & 88 & This study \\
\hline
\end{tabular}

annual rainfall of 565-1500 $\mathrm{mm}$ (Table 4). Using plot sizes of $0.04-0.25$ ha and sample sizes of 2-247 plots, a total number of species ranging from $40(\mathrm{Dbh} \geq 10 \mathrm{~cm})$ to $229(\mathrm{Dbh} \geq 2 \mathrm{~cm})$ have been reported from Miombo woodlands [22, 25-28, 4345].

The high number of species reported by Banda et al. [26], Chidumayo [22], Isango [45], and Chamshama et al. [44] is likely to be a consequence of the spatial scale and coverage of these studies as they all cover large areas, include more than one site, and operate with large sample sizes. For example, Chidumayo [22] included species from both wet and dry Miombo areas in Zambia. The study by Sauer and Abdallah [15], who reported a total of 131 species occurring in the tobacco growing zone of Iringa rural district, included two forest reserves and three family-managed forests. Therefore, considering the climatic conditions in the GVLFR $(617 \mathrm{~mm}$ of rainfall per year) and the sample size (35 plots), the species richness reported in this study can be ranked at least as high or higher than those found in the studies mentioned. The selective sampling approach, focusing on various microhabitat types, adopted by Banda et al. [26] may have contributed to the large number of species observed in their study area. Similarly, the higher number of species found by Giliba et al. [27] was probably due to the presence of riverine forest, offering site conditions favourable for many species.

The values of the Shannon-Wiener $\left(H^{\prime}=3.44\right)$ and Simpson indices $(D=0.05)$ reported for large individuals in this study are within the range observed for most communities of particular life forms [36]. For example, $H^{\prime}$ usually does not exceed 5 , although this maximum value varies depending on the type of the biological community sampled and the sampling approach applied (e.g., minimum diameter and size of sample units). A threshold value of 2 for $H^{\prime}$ has been mentioned as a minimum value, above which an ecosystem can be regarded as medium to highly diverse [27]. Chamshama et al. [44] reported three $H^{\prime}$ values of 3.1, 3.2, and 3.3 from Kitulangalo Miombo forest in Eastern Tanzania, while Njana [43] reported a $H^{\prime}$ value of 3.40 from dry Miombo forest in Western Tanzania. The studies by Sauer and Abdallah [15] and Giliba et al. [27] reported particularly high values of 3.46 and 4.27 , respectively. This could be attributed to the very large sample sizes used in both studies and the presence of riverine forest where the chance of encountering many rare species is likely to be high. The forests examined in the mentioned studies receive an average annual rainfall of 700-1000 $\mathrm{mm}$, compared to which the rainfall in the GVLFR is low ( $617 \mathrm{~mm}$ on average per year, c.f. above). The relatively high diversity found in GVLFR must therefore be attributed to other factors than climate. The soil analyses indicate that the soil fertility level in the GVLFR is relatively high, with considerable proportions of all $2: 1$ lattice clay minerals (114\%) (i.e., illite, montmorillonite, and vermiculite) plus a good amount of organic matter, which may suggest that the soil has large reserves of important plant nutrients, for example, $\mathrm{K}, \mathrm{Mg}$, and $\mathrm{Fe}$. The base saturation percentage (BS), which is normally used to indicate the soil fertility status (Landon, 1991), was also high, $76 \%$ on average, and with $86 \%$ of the samples (30 samples) with BS values $>50 \%$ (fertile soil), and only $14 \%$ of the samples (5 samples) with BS below $50 \%$ (less fertile soil). As another indication of high soil fertility status the mean $\mathrm{C}: \mathrm{N}$ ratio was $12 \pm 0.43$ 
(range 7-19) for top soil $(0-15 \mathrm{~cm})$ and $11 \pm 0.36$ (range 516) for subsoil $(15-30 \mathrm{~cm})$. In general, the values for both soil strata fall within the expected range of $8-17$. Soil $\mathrm{pH}$ values (mean $6.7 \pm 0.1$, range 5.67-8.52) were also within the optimal range where all the nutrients that are most important for plant growth ( $\mathrm{Ca}, \mathrm{Mg}, \mathrm{K}$, and $\mathrm{P}$ ) are available and accessible to plants [46]. In this study, $97 \%$ of the soil samples had $\mathrm{pH}$ below 8 (one sample had a $\mathrm{pH}$ of 8.52 ). Fisher and Binkley [47] noted that high $\mathrm{pH}$ is almost never a problem in forests as most trees do well across the full range of common $\mathrm{pH}$ values. Therefore, considering the low average annual rainfall compared to other forests, the relatively high fertility of the GVLFR may be the main factor creating an environment favourable to many species, thus leading to a quite high species diversity observed in this forest.

Based on the Importance Value Index Brachystegia spiciformis and Combretum molle appeared to be the most important species among harvested trees (stumps) in the study area. This result agreed very well with the large values of basal area and volume and the information obtained from local scouts and members of the village environmental committee, who said that the most frequently harvested species for charcoal making include all Brachystegia species found in the forest (i.e., Brachystegia spiciformis, Brachystegia manga, Brachystegia boehmii, and Brachystegia bussei). Among the Combretum species, the most important one (based on IVI), Combretum molle, is mostly used for house construction and firewood rather than for charcoal making. Apart from the Brachystegia species, the only other species mentioned as important for charcoal making was Acacia mellifera. Other species are only used in case they happen to fall when felling the preferred species during the preparation of charcoal kilns. With respect to stumps, Brachystegia spiciformis, Brachystegia manga, and Combretum molle are among the ten most abundant species in terms of density, basal area, and volume per hectare. Stumps of the other species mentioned are not commonly found, a fact which may be due to the small sample size being unable to capture sites where these species are harvested but may also be related to their limited distribution in the forest as indicated by the estimated dispersion indices (see Table 1).

4.2. Forest Structure. Species densities reported from other Miombo woodland areas in Tanzania are typically 348-1495 stems/ha for trees with Dbh $>4 \mathrm{~cm}[24,43,45]$. Compared with this the GVLFR is highly stocked as the estimated density is 2296 stems/ha for trees with $\mathrm{Dbh}>4 \mathrm{~cm}$. The mean stem density of $1521 \pm 594 /$ ha for trees with $\mathrm{Dbh} \geq 5 \mathrm{~cm}$ is also more than twice as large as values found in other studies [25-27, 44, 45, 48]. A similar pattern is seen when comparing the density of regeneration between the studies. The diameter distribution is characterised by a very clear trend of decreasing stem density with increasing diameter. The shape of the distribution is thus an inverted "J" (Figure 3), which is a common feature of natural forests with active regeneration and recruitment [49]. However, not many large trees were captured by the sample, whereas a considerable number of relatively large stumps were observed, suggesting that anthropogenic activities such as charcoal making may have affected the structure and ecological balance of the forest (see Figure 3). Since the woodlands are often hit by fire which tends to kill the seedlings (especially the late fires) and thus only few seedlings can be expected to reach larger diameter classes, lack of mature trees and the resulting lack of seeds may eventually threaten the biodiversity of the forest.

The mean basal area of $13.55 \pm 5.52 \mathrm{~m}^{2} /$ ha observed in this study is slightly above the range of values typically reported from the miombo region, $7.5-12.6 \mathrm{~m}^{2} / \mathrm{ha}[26,28,43$, $44,50]$. However, the basal areas reported by Isango [45] were a bit higher (15.04-15.63 $\left.\mathrm{m}^{2} / \mathrm{ha}\right)$ than observed in this study.

The mean total volume in GVLFR was estimated at 92.17 \pm $39.0 \mathrm{~m}^{3} /$ ha for trees with $\mathrm{Dbh} \geq 5 \mathrm{~cm}$. Other studies in dry Miombo woodlands have reported mean volumes of 16.7$76.03 \mathrm{~m}^{3} /$ ha $[24,44,45,50]$. The current standing volume of GVLFR is thus slightly higher than values typically reported for forests in the Miombo ecoregion. A plausible reason for this may be that, compared to other forests, the GVLFR is still well stocked despite ongoing human activities such as charcoal making. The basal area observed for stumps was only $0.72 \mathrm{~m}^{2} /$ ha so there is no indication of intensive extraction over many years. This corresponds well with the findings of Treue et al. [20] who conclude that the estimated $0.4 \mathrm{~m}^{3} / \mathrm{ha}$ annual extraction of woody biomass from GVLFR is considerably below its estimated annual increment of $1.5 \mathrm{~m}^{3} /$ ha and that the local forest managers seem capable of regulating the harvesting activities, which, in addition to village members' collection for subsistence uses, also included commercial charcoal production by external companies that pay a fee per bag of charcoal extracted to the village government.

4.3. Plant Communities and Species Associations. Except for Brachystegia spiciformis, the majority of the Brachystegia and Julbernardia species that are common to miombo woodlands elsewhere are not among the species most commonly observed in this study. A similar pattern was observed by Banda et al. [26] in the Katavi-Rukwa ecosystem where the genera that are most common in miombo woodlands, Brachystegia, Julbernardia, and Isoberlinia, were not common in their study sites. Furthermore the four plant communities distinguished in this study are comparable with those reported by other studies in Tanzania, including the work by Munishi et al. [29] in the Miombo woodlands of Rukwa basin, Chunya district, Tanzania, and the study by Banda et al. [26] in the Katavi-Rukwa ecosystem.

Elevation was noted by Munishi et al. [29] to be the most important factor shaping the species communities in their study area. This study found a similar pattern with the highest coefficient of correlation observed for elevation, suggesting that topographical variation is among the strongest determinants of community composition in dry Miombo woodlands, hence influencing the spatial distribution of species strongly. However, in our study area edaphic factors also influenced the species distribution directly. Two plant communities occurred mainly on clayey soils with high $\mathrm{pH}$ at intermediate elevations, one on sandy soils with low $\mathrm{pH}$ at low elevations and one on sandy-clayey soils at higher elevations and with neutral soil pH (Figure 5). Specifically, it appeared 
that the Acacia woodland category (Community 5) grows at low elevations around temporary streams (or at least where the ground water table is relatively high), and the Bauhinia woodland category (Community 24) appears mostly in places with a relatively high percentage of clay (and therefore high values of $\mathrm{pH}, \mathrm{Ca}$, and $\mathrm{BS}$ ). By contrast it appeared that the Dalbergia woodland category (Community 3 ) is located at more sandy sites (with low values of $\mathrm{pH}, \mathrm{Ca}$, and $\mathrm{BS}$ ), and the Brachystegia woodland category (Community 1) seemed to be located mostly at higher elevations where the CNratio is quite high. Correlations between elevation and the basic soil variables $\mathrm{pH}, \mathrm{Ca}$, and percentages of sand and clay were low (c.f. Figure 5). Thus, the results indicate that the plant communities of the dry miombo woodlands in GVLFR are not only shaped by the topographic variation (elevation) and the groundwater level but also by basic soil characteristics. The results thus confirm findings from other studies detecting effects of elevation and soil characteristics on species composition $[51,52]$.

\section{Conclusion}

Considering that the sample size used in this study was smaller than samples used in other studies in dry miombo woodlands, the results show that the species diversity in GVLFR is relatively high compared to other forest reserves. The vegetation of GVLFR is characterised by high density, basal area, and volume, and despite the scarcity of large diameter trees this indicates that the forest is in a good condition. The effect of anthropogenic activities is nevertheless evident and stresses the need for proper management, especially for economically important species preferred for charcoal making, (e.g., Brachystegia spiciformis), if the current species diversity is to be maintained or enhanced. A repeated future study would be needed to assess whether the current community-based management regime yields this intended outcome, but the available information and analyses allow for some optimism in this respect.

\section{Conflict of Interests}

The authors declare that there is no conflict of interests regarding the publication of this paper.

\section{Acknowledgments}

The authors wish to thank people from Mfyome village for their invaluable assistance during field work: Mzee Iddi Kaheya, Damian Chotamasege, Augustino Mkwama, Liberatus Simime, and Mawazo Nyangwa. Furthermore, thanks are due to Venancia Mlelwa from Sokoine University and Mads Madsen Krag from University of Copenhagen for doing the laboratory work. The authors also wish to thank Goodluck Moshi, their driver, Marco Njana and Nassoro H. Magogo, the TAFORI botanist for assisting with species identification, and Klaus Dons for preparing a study site map. Financial support was provided by Danida through the ENRECA Project,
"Participatory forest management for rural livelihoods, forest conservation and good governance in Tanzania" (no. 725).

\section{References}

[1] P. G. H. Frost, "The Ecology of Miombo Woodlands," in The Miombo in Transition: Woodlands and Welfare in Africa, B. Campbell, Ed., pp. 11-57, 1996.

[2] N. Burgess, J. Hales, E. Underwood et al., Terrestrial Ecoregions of Africa and Madagascar: A Conservation Assessment, Island Press, World Wildlife Fund, 2004.

[3] J. Clarke, W. Cavendish, and C. Coote, "Rural households and miombo woodlands: use, value and management," in The Miombo in Transition: Woodlands and Welfare in Africa, B. Campbell, Ed., pp. 101-135, 1996.

[4] B. M. Campbell, A. Angelsen, A. Cunningham, Y. Katerere, A. Sitoe, and S. Wunder, "Miombo woodlands-opportunities and barriers to sustainable forest management," https://energypedia.info/images/6/6d/Miombo2007.pdf.

[5] S. Syampungani, P. W. Chirwa, F. K. Akinnifesi, G. Sileshi, and O. C. Ajayi, "The Miombo woodlands at the cross roads: potential threats, sustainable livelihoods, policy gaps and challenges," Natural Resources Forum, vol. 33, no. 2, pp. 150-159, 2009.

[6] J. I. O. Abbot and K. Homewood, "A history of change: causes of miombo woodland decline in a protected area in Malawi," Journal of Applied Ecology, vol. 36, no. 3, pp. 422-433, 1999.

[7] E. J. Luoga, E. T. F. Witkowski, and K. Balkwill, "Land cover and use changes in relation to the institutional framework and tenure of land and resources in eastern Tanzania Miombo woodlands," Environment, Development and Sustainability, vol. 7, no. 1, pp. 71-93, 2005.

[8] FAO, The State of Food and Agriculture 2010-2011, Forest and Agriculture Organization, Rome, Italy, 2010.

[9] A. H. Gentry, "Tropical forest biodiversity: distributional patterns and their conservational significance," Oikos, vol. 63, no. 1, pp. 19-28, 1992.

[10] O. E. Sala, F. S. Chapin III, J. J. Armesto et al., "Global biodiversity scenarios for the year 2100," Science, vol. 287, no. 5459, pp. 1770-1774, 2000.

[11] H. J. Geist and E. F. Lambin, "Proximate causes and underlying driving forces of tropical deforestation," BioScience, vol. 52, no. 2, pp. 143-150, 2002.

[12] R. S. DeFries, "Tropical forests deforestation and ecosystems services Contributions of remote sensing," in Geoinformatics For Tropical Ecosystems, P. S. Roy, Ed., pp. 1-32, 2003.

[13] B. M. Campbell, P. Frost, and N. Bryon, "Miombo woodlands and their use: overview and key issues," in The Miombo in Transition: Woodlands and Welfare in Africa, B. Campbell, Ed., pp. 1-10, 2006.

[14] H. J. Geist, "Global assessment of deforestation related to tobacco farming," Tobacco Control, vol. 8, no. 1, pp. 18-28, 1999.

[15] J. Sauer and J. M. Abdallah, "Forest diversity, tobacco production and resource management in Tanzania," Forest Policy and Economics, vol. 9, no. 5, pp. 421-439, 2007.

[16] E. N. Chidumayo and K. J. Mbata, "Shifting cultivation, edible caterpillars and livelihoods in the Kopa area of northern Zambia," Forests Trees and Livelihoods, vol. 12, no. 3, pp. 175-193, 2002.

[17] E. N. Chidumayo and L. Kwibisa, "Effects of deforestation on grass biomass and soil nutrient status in miombo woodland, Zambia," Agriculture, Ecosystems and Environment, vol. 96, no. 1-3, pp. 97-105, 2003. 
[18] J. F. Lund and T. Treue, "Are we getting there? Evidence of decentralized forest management from the Tanzanian miombo woodlands," World Development, vol. 36, no. 12, pp. 2780-2800, 2008.

[19] T. Blomley and S. Iddi, Participatory Forest Management in Tanzania: 1993-2009-Lessons Learned and Experiences to Date, Ministry of Natural Resources and Tourism, Forestry and Beekeeping Division, Dar es Salaam, Tanzania, 2009.

[20] T. Treue, Y. M. Ngaga, H. Meilby et al., "Does participatory forest management promote sustainable forest utilisation in Tanzania?" International Forestry Review, vol. 16, no. 1, pp. 1-16, 2014.

[21] Ministry of Natural Resources and Tourism, Participatory Forest Management in Tanzania. Facts and Figures, Forestry and Beekeeping Division, Dar es Salaam, Tanzania, 2008.

[22] E. N. Chidumayo, "Species structure in Zambian miombo woodland," Journal of Tropical Ecology, vol. 3, no. 2, pp. 109-118, 1987.

[23] J. D. Lowore, "Coppice regeneration in some miombo woodlands of Malawi," FRIM Report 99001, Forestry Research Institute of Malawi, 1999.

[24] E. J. Luoga, E. T. F. Witkowski, and K. Balkwill, "Harvested and standing wood stocks in protected and communal miombo woodlands of eastern Tanzania," Forest Ecology and Management, vol. 164, no. 1-3, pp. 15-30, 2002.

[25] M. Williams, C. M. Ryan, R. M. Rees, E. Sambane, J. Fernando, and J. Grace, "Carbon sequestration and biodiversity of regrowing miombo woodlands in Mozambique," Forest Ecology and Management, vol. 254, no. 2, pp. 145-155, 2008.

[26] T. Banda, N. Mwangulango, B. Meyer et al., "The woodland vegetation of the Katavi-Rukwa ecosystem in western Tanzania," Forest Ecology and Management, vol. 255, no. 8-9, pp. 3382-3395, 2008.

[27] R. A. Giliba, E. K. Boon, C. J. Kayombo, E. B. Musamba, A. M. Kashindye, and P. F. Shayo, "Species composition, richness and diversity in Miombo Woodland of Bereku Forest Reserve Tanzania," Journal of Biodiversity, vol. 2, no. 1, pp. 1-7, 2011.

[28] D. D. Shirima, P. K. T. Munishi, S. L. Lewis et al., "Carbon storage, structure and composition of miombo woodlands in Tanzania's Eastern Arc Mountains," African Journal of Ecology, vol. 49, no. 3, pp. 332-342, 2011.

[29] P. K. T. Munishi, R. A. P. C. Temu, and G. Soka, "Plant communities and tree species associations in a Miombo ecosystem in the Lake Rukwa basin, Southern Tanzania: implications for conservation," Journal of Ecology and Natural Environment, vol. 3, no. 2, pp. 63-71, 2011.

[30] J. Dewis and F. Freitas, "Physical analysis of soils", in Physical and Chemical Methods of Soil and Water Analysis, FAO Bulletin no. 10, pp. 51-57, 2nd edition, 1970.

[31] S. R. Olsen and L. E. Sommers, "Phosphorus," in Methods of Soil Analysis, Part 2, Agronomy Monograph, No 9, A. L. Page, R. H. Miller, and P. R. Keeney, Eds., pp. 403-430, American Society of Agronomy, Madson, Wis, USA, 1982.

[32] J. D. Rhoades, "Cation exchange capacity," in Methods of Soil Analysis, Part 2, Agronomy Monograph No. 9, A. L. Page, R. H. Miller, and P. R. Keeney, Eds., pp. 149-157, American Society of Agronomy, Madson, Wis, USA, 1982.

[33] I. Matejovic, "Determination of carbon, hydrogen, and nitrogen in soils by automated elemental analysis (dry combustion method)," Communications in Soil Science and Plant Analysis, vol. 24, no. 17-18, pp. 2213-2222, 1993.
[34] J. P. Møberg, Soil Analysis Manual, Revised Edition, Laboratory of Soil Sciences, Department of Soil Science, Sokoine University of Agriculture, Morogoro, Tanzania, 2001.

[35] N. C. Brady, The Nature and Properties of Soils, Macmillan, 8th edition, 1974.

[36] C. J. Krebs, Ecological Methodology, Hamper Collins Publishers, New York, NY, USA, 2nd edition, 1999.

[37] B. Husch, T. W. Beers, and J. A. Kershaw, Forest Mensuration, John Wiley \& Sons, Hoboken, NJ, USA, 4th edition, 2003.

[38] E. E. Mwakalukwa, H. Meilby, and T. Treue, "Volume and aboveground biomass models for dry Miombo Woodland in Tanzania," In press.

[39] M. Kent, Vegetation Description and Analysis, A Practical Approach, Wiley-Blackwell, John Wiley \& Sons, Hoboken, NJ, USA, 2nd edition, 2012.

[40] B. McCune and M. J. Mefford, PC-ORD. Multivariate Analysis of Ecological Data, Version 6, MjM Software, Gleneden Beach, Ore, USA, 2011.

[41] M. Dufrene and P. Legendre, "Species assemblages and indicator species: the need for a flexible asymmetrical approach," Ecology Monography, vol. 67, pp. 777-795, 1997.

[42] J. E. Peck, Multivariate Analysis for Community Ecologists: Stepby-Step using PC-ORD, MjM Software Design, Gleneden Beach, Ore, USA, 2010.

[43] M. A. Njana, Arborescent species diversity and stocking in Miombo Woodland of Urumwa forest reserve and their contribution to Livelihoods, Tabora, Tanzania [M.S. thesis], Sokoine University of Agriculture, Morogoro, Tanzania, 2008.

[44] S. A. O. Chamshama, A. G. Mugasha, and E. Zahabu, "Stand biomass and volume estimation for Miombo woodlands at Kitulangalo, Morogoro, Tanzania," Southern African Forestry Journal, no. 200, pp. 59-70, 2004.

[45] J. Isango, "Stand structure and tree species composition of Tanzania miombo woodlands: a case study from miombo woodlands of community based forest management in Iringa district," in MITMIOMBO-Management of Indigenous Tree Species For Ecosystem Restoration and Wood Production in SemiArid Miombo Woodlands in Eastern Africa, Proceedings of the 1st MITMIOMBO Project Workshop held in Morogoro, Tanzania, 6th-12th February 2007. Working Papers of the Finnish Forest Research Institute no. 50, pp. 43-56, 2007.

[46] J. R. Landon, Booker Tropical Soil Manual. A Handbook For Soil Survey and Agricultural Land Evaluation in the Tropics and Subtropics, Longman Scientific \& Technical and John Wiley \& Sons, 1991.

[47] R. F. Fisher and D. Binkley, Ecology and Management of Forest Soils, John Wiley \& Sons, 3rd edition, 2000.

[48] W. A. Rees, "Preliminary studies into bush utilization by Cattle in Zambia," Journal of Applied Ecology, vol. 11, pp. 207-214, 1974.

[49] S. M. Philip, Measuring Trees and Forests, CAB International, Wallingford, UK, 2nd edition, 1994.

[50] J. D. Lowore, P. G. Abbot, and M. Werren, "Stackwood volume estimations for miombo woodlands in Malawi," Commonwealth Forestry Review, vol. 73, no. 3, pp. 193-197, 1994.

[51] D. Kubota, T. Masunaga, Hermansah et al., "Soil environment and tree species diversity in tropical rain forest, West Sumatra, Indonesia," in Soils of Tropical Forest Ecosystems. Characteristics, Ecology and Management, A. Schulte and D. Ruhiyat, Eds., pp. 159-167, 1998.

[52] P. K. T. Munishi, T. H. Shear, T. Wentworth, and R. A. P. C. Temu, "Compositional gradients of plant communities in submontane rainforests of Eastern Tanzania," Journal of Tropical Forest Science, vol. 19, no. 1, pp. 35-45, 2007. 

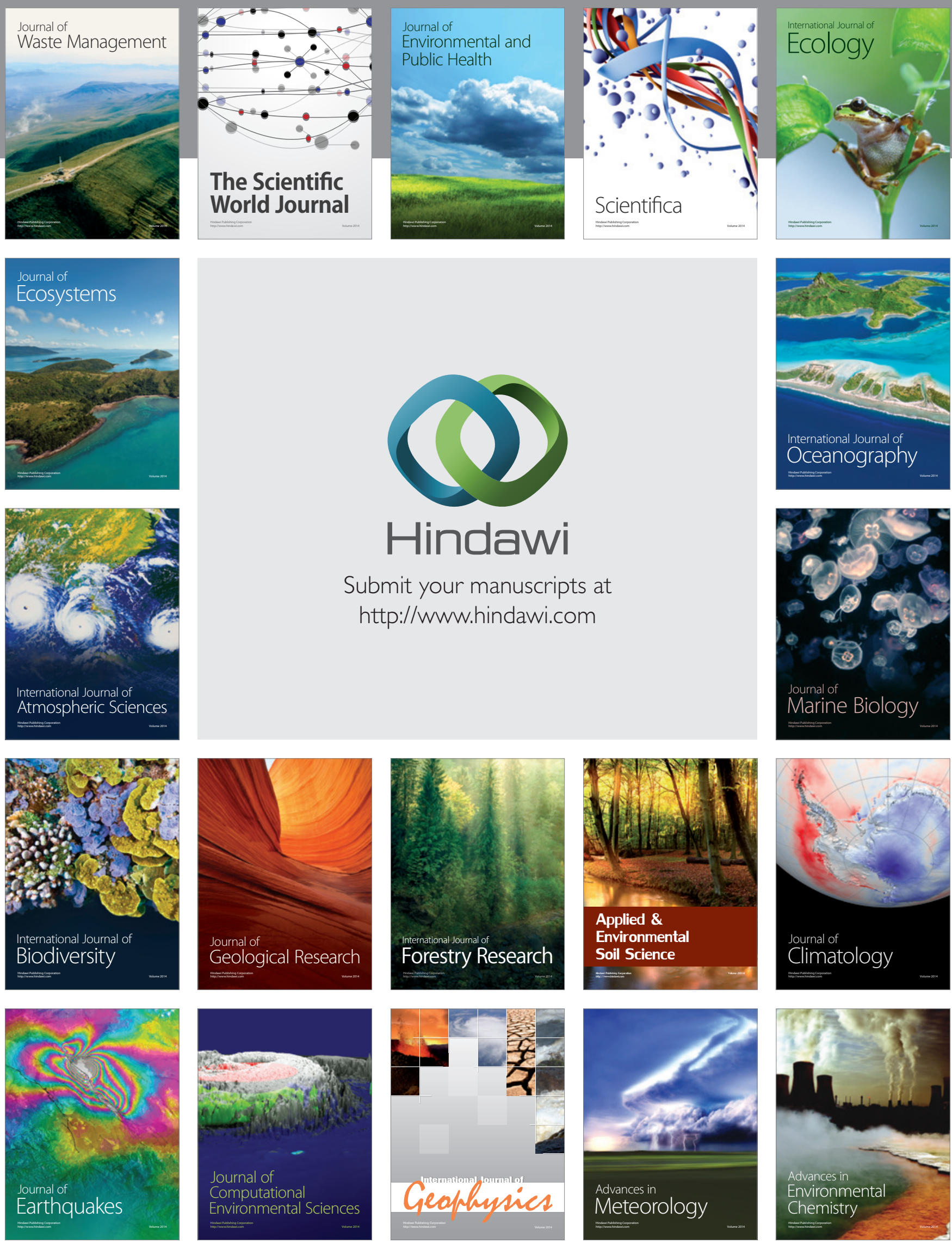